DOI: 10.17951/lrp.2019.38.1.97-112

\title{
MARIA WieczoreK
}

Uniwersytet Szczeciński

ORCID 0000-0002-5442-9596

\section{KREATYWNOŚĆ PROJEKTANTÓW ZABAWEK ZATRUDNIONYCH W SPÓŁDZIELNIACH PRACY W OKRESIE PRL A CZYNNIKI JĄ OGRANICZAJĄCE}

\author{
Zabawka stanowi pierwsze dzieło sztuki, \\ z jakim styka się człowiek u progu drogi swojego życia \\ Maksim Gorki
}

Streszczenie: W 1980 roku Janos Kornai opublikował pracę pt. „Gospodarka niedoboru”. Zdefiniował w ten sposób centralnie sterowaną gospodarkę komunistyczną. Także w Polskiej Rzeczpospolitej Ludowej, kraju, w którym po II wojnie światowej władzę przejęła Polska Zjednoczona Partia Robotnicza, brakowało wielu artykułów. Choć osobom żyjącym w czasach PRL w pamięci zapisał się głównie brak podstawowych artykułów spożywczych czy przemysłowych, także ilość (i jakość) zabawek pozostawiała wiele do życzenia. Brakowało nie tylko tanin, surowców i innych materiałów potrzebnych do produkcji zabawek, ale także specjalistycznych maszyn i innych urządzeń. Nie było także odpowiedniej ilości wykwalifikowanych pracowników, m.in. z tego powodu w okresie PRL-u nie każde przedsiębiorstwo produkujące zabawki zatrudniało własnych projektantów.

Mimo to w spółdzielniach pracy (bo to właśnie stamtąd pochodziła większość lalek czy samochodzików, które można było kupić w sklepach czy kioskach Ruchu) powstawało wiele ciekawych wzorów. W artykule opisałam zarówno działalność zakładowych wzorcowni i prototypowni, jak i przywołałam nazwiska projektantów pracujących w przemyśle zabawkarskim.

Słowa kluczowe: zabawki, PRL, kreatywność, projektanci, historia, spółdzielnie

\section{WPROWADZENIE}

„Błyszczące kolorowymi złotkami yoyo, miniaturowe pianina, konik na biegunach, bierki, kolejka, a także plastikowe elementy przypominające pinezki, które 
wciskało się w planszę i tworzyło wzory. A poza tym, choć może to nie zabawka, projektor Ania, na którym puszczało się bajki..." - tak w świadomości wielu osób, których dzieciństwo przypadło na lata 70. i 80. XX wieku zapisały się zabawki obecne w tym okresie w Polsce. Lalki Barbie czy samochody Matchbox nie były wówczas powszechnie dostępne, na ich zakup w Pewexach mogli sobie pozwolić nieliczni - ci, którzy dysponowali dewizami. Duża część zabawek oferowanych w sklepach czy kioskach „Ruchu” wytwarzana była w polskich przedsiębiorstwach, przede wszystkim w spółdzielniach pracy, niewielkie ilości importowano (głównie były to kolejki Pico dostępne np. w Centralnych Składnicach Harcerskich).

Poza autami, klockami czy lalkami wytwarzanymi w spółdzielniach zabawki (głównie ludowe) kupowano na odpustach - dotyczyło to przede wszystkim mniejszych miast. W większych można było zrobić zakupy w komisach, choć sprzedawano tam dość drogie zabawki sprowadzane z zagranicy. Ponieważ nie było oficjalnych ograniczeń co do wykonywania zawodu, żołnierzyki czy miniaturowe komplety naczyń dla lalek mógł produkować każdy, wytwarzało je też wielu rzemieślników. Choć pracownikom przemysłu zabawkarskiego doskwierał brak podstawowych surowców, maszyn i narzędzi, a w przedsiębiorstwach powstawały zabawki różnej jakości, wiele modeli było bardzo udanych. Kreatywność i pomysłowość artystów ograniczona była wszechobecnymi niedoborami - mimo to w spółdzielniach projektowano wiele ciekawych wzorów. Ponieważ to właśnie w spółdzielniach pracy wytwarzano większość zabawek dostępnych w sklepach, przedstawię historię ich rozwoju, a także bolączki pracujących tam osób - wśród nich projektantów.

\section{„CEPELIA” A ZABAWKI}

W lipcu 1945 roku spośród znajdujących się na ziemiach polskich 30 zakładów produkujących instrumenty muzyczne i zabawki czynnych było 22 (w tym 10 na tzw. ziemiach odzyskanych, wśród nich 8 czynnych). Aż w 11 były zniszczone budynki przemysłowe, w 6 - gospodarka energetyczna a w 13 - urządzenia techniczne ${ }^{2}$. W 18 zatrudniano (według stanu z dnia 31 sierpnia 1946 roku) pięciu i więcej pracowników. Odnalezienie się w nowej rzeczywistości nie było łatwe, choć dość szybko po zakończeniu działań na nowo uruchomiły produkcję przedsiębiorstwa mające swój początek w dwudziestoleciu międzywojennym, np. już w czerwcu 1945 roku lalki wytwarzano w Częstochowskiej Fabryce Wyrobów Celuloidowych (przed wojną z dopiskiem „Kosmos”, później posługującą się skrótem CFWC)

${ }^{1}$ Na podstawie rozmów z osobami, których dzieciństwo przypadło na lata 70. i 80. XX wieku, przeprowadzonych we wrześniu 2013 roku.

2 Dane pochodzą z Rocznika Statystycznego, GUS, Warszawa 1947, s. 70-71. 
a „Gazecie Ludowej” z 7 marca 1946 roku informowano, że znana w okresie międzywojennym Fabryka Zabawek „Bambino” (z siedzibą w Warszawie przy ul. Elekcyjnej 37) wznowiła produkcję zabawek wypychanych. Funkcjonowały także inne niewielkie fabryki zabawek. Jedną z pierwszych była założona w 1946 roku przez Wacława Maliszewskiego w Cieplicach Śląskich „Zorka”, z kolei z 1947 roku pochodzi informacja o fabryczce działającej w Złoczewie koło Sieradza i produkującej zabawki z ceraty i filcu (sprzedawane w Polsce i wysyłane do Anglii).

Ilość zabawek po II wojnie światowej nie była wystarczająca, liczyła się więc każda inicjatywa, która miała na celu poprawienie sytuacji na rynku. Organizowano m.in. specjalne kursy instruktorskie (np. w 1948 roku taki kurs odbył się w Szkole Przemysłowej Żeńskiej w Kielcach), których celem była likwidacja bezrobocia wśród kobiet i jednocześnie wykorzystanie odpadków włókienniczych, odzieżowych, galanteryjnych i skórzanych. W kursach uczestniczyły m.in. utalentowane plastyczki, np. Anna Jasińska z Łodzi, Czesława Rosyk z Bielska i Anna Narzymska ${ }^{3}$ z Kielc.

W drugiej połowie lat 40. XX w. przemysł (również zabawkarski) został znacjonalizowany, a „masową produkcją zabawek w Polsce powojennej zajęły się wówczas wyrastające jak grzyby po deszczu spółdzielnie” (Górecka 2009, s. 161). Inną z konsekwencji nowego ustroju było nieprzywiązywanie wagi do autorstwa danego projektu - przede wszystkim z tego powodu wielu wyprodukowanym w latach. 50.-80. XX w. zabawek nie można przypisać konkretnym osobom.

Sytuacja zarówno spółdzielni, jak i całego przemysłu zabawkarskiego, uległa diametralnej zmianie (na lepsze) w 1949 roku. Utworzono wówczas Spółdzielczo-Państwową Centralę Przemysłu Ludowego i Artystycznego (od 1955 roku znaną pod nazwą „Cepelia”), która skupiła 16 spółdzielni oraz zakładów prywatnych zatrudniających m.in. rzemieślników dobrze znających fach, ponieważ wytwórczością zabawek zajmowali się jeszcze przed wybuchem wojny. Oprócz doświadczonych „zabawkarzy” zatrudniano m.in. artystów, psychologów i pedagogów, dlatego pod koniec lat 40. i na początku 50. zabawki sygnowane przez Cepelię były bardzo dobrej jakości - o czym świadczyć może choćby ich eksport poza granice kraju. W Łomiankach powstał Zakład Doświadczalny (wytwarzano tam zabawki z drewna, m.in. pociągi), swoją działalność rozpoczęło też Biuro Studiów i Projektów Przemysłu Zabawkarskiego.

W 1953 roku w Łodzi został utworzony Zarząd Przemysłu Zabawkarskiego. Przejął on „wytwórnie zabawek, istniejące w państwowym przemyśle terenowym oraz Zakład Doświadczalny w Łomiankach, którego zadaniem było wykonywanie

${ }^{3}$ Monograficzną wystawę „Filc i spółka. Zabawki Anny Narzymskiej-Prauss” można było oglądać do 6 września 2018 roku w Muzeum Zabawek i Zabawy w Kielcach. 
prototypów, wzorów i modeli zabawek drewnianych. Powołana też została Komisja Kwalifikacyjno-Selekcyjna, której zadaniem była selekcja wytwarzanych zabawek i ocena wzorów wprowadzanych do produkcji" (Rozwój produkcji zabawkarskiej, 1987, s. 9). W tym samym czasie (w latach 1953-54) funkcjonowały też tzw. nadzory artystyczne. Była to współpraca pomiędzy artystami-plastykami a kierownictwem technicznym wytwórni. „Początkowo obie strony podchodziły do siebie bardzo nieufnie, jednak - gdy artysta-plastyk zrozumiał wymagania technologiczne, a technolog zgodził się z żądaniem plastyka - nastąpiła harmonijna współpraca przynosząca ogromne korzyści dla jakości i estetyki produkcji. Z tego okresu datują się doskonałe osiągnięcia artystów-plastyków: Narzymskiej [Anny - przyp. M.W.] z Kielc (produkcja lalek), Rosnerowej z Warszawy (produkcja zwierząt z tkanin), Kosickiej z Warszawy (projekty rzeźby główek, zwierząt i całych lalek). W tym czasie wybiły się talenty w produkcji zabawkarskiej - Strzemieniowej w Kielcach, Getterowej we Wrocławiu, Wróbel Janiny w Warszawie" (Piętowski, Witaczek 1957, s. 13). Wzory zabawek powstawały wówczas w biurze konstrukcyjnym, które zostało powołane specjalnie $\mathrm{w}$ tym celu.

Te działania zostały jednak uznane przez władze centralne podczas II zjazdu PZPR w 1954 roku za niewystarczające, a stan rozwoju produkcji zabawkarskiej za niedostateczny, dlatego $\mathrm{w}$ tym samym czasie podjęto decyzję o wyłączeniu produkcji zabawek z zakresu działania Cepelii ${ }^{4}$. Od stycznia 1955 roku spółdzielnie przeszły pod opiekę Centralnego Związku Spółdzielczości Pracy. W 1957 roku zlikwidowano też Biuro Studiów i Projektów Przemysłu Zabawkarskiego, Zarząd Przemysłu Zabawkarskiego w Łodzi oraz Zakład Doświadczalny, co bezpośrednio wpłynęło na gwałtowne zahamowanie rozwoju tej gałęzi.

„W drugiej połowie lat pięćdziesiątych na rynku w coraz szerszym zakresie zaczęły pojawiać się zabawki z tworzyw sztucznych, które jako nowości skutecznie konkurowały z zabawkami tradycyjnymi” (Strzelec 1989, s. 51), więc niektórzy producenci zaczęli obawiać się o sprzedaż swoich wyrobów. Wprowadzenie tworzyw sztucznych (z czasem upowszechnił się przede wszystkim polistyren i polipropylen) miało znaczenie przełomowe w wytwórczości zabawek „przyczyniając się do znacznego wzbogacenia ilościowego i asortymentowego tej produkcji" (Rozwój produkcji zabawkarskiej, 1987, s. 10-11). Najlepszym przykładem jest wprowadzenie na rynek przez krakowską Chemiczną Spółdzielnię Pracy „Pomoc” w 1955 roku pierwszej w Polsce lalki z polichlorku winylu. Lalki wykonane z tego materiału bardzo szybko zyskały popularność, zarówno w kraju, jak i za granicą, a spółdzielnia od razu zaczęła poszerzać ich asortyment wprowadzając

${ }^{4}$ Więcej o Cepelii patrz P. Korduba Ludowość na sprzedaż, Warszawa 2013 oraz R. Gmurczyk Organizacja cepeliowska w latach 1949-2014. Fakty i ludzie, Warszawa 2014. 
nowo opracowane wzory. Na specjalne zamówienie PZPN lalki - drużynę „Orłów” (w ilości 500 sztuk) zaprojektował znany krakowski plastyk Bronisław Chromy. Ponieważ w spółdzielni wciąż nie było komórki wzorcującej, projektowaniem zajmował się... prezes spółdzielni Władysław Zawiślak. To on był twórcą jednych z najsłynniejszych lal tamtego okresu - „Oli” i „Ali” (za ich estetyczne wykonanie odpowiedzialny był kierownik techniczny Tadeusz Lech). „Bliźniaczki” otrzymały srebrny medal w konkursie „Dobre - Ładne - Poszukiwane” organizowanym w Poznaniu podczas Targów Krajowych „Wiosna’ 66”. „Lalki wyposażone są w zmienne peruki [trzy - rudą, blond i czarną - przyp. M.W.] oraz kilka [pięć, cztery sukienki gotowe i jedną dodaną do samodzielnego uszycia - przyp. M.W.] kompletów strojów, nie wyłączając ślubnej sukni. «Pomoc» prezentowała 24 wzory lalek. Oprócz Oli i Ali furorę zrobiły również lalki o wdzięcznych nazwach: Paulinka i Irenka" (AS 1966, s. 1).

Lalki można było kupić zarówno ubrane jak i tzw. „naguski”, czyli bez strojów. Były nie tylko ładne, ale i praktyczne - „ustępująca jak guma pod naciskiem palca masa o kolorze identycznym jak ciało dziecka, łączy w sobie wszystkie walory estetyki, trwałości, bezpiecznej zabawy i nauki” (Piętowski, Witaczek 1957, s. 206).

\section{PROCES PRZEMIAN}

Na przełomie lat 50. i 60., pisząc o brzydkich zabawkach, konkludowano: „Na estetyce zabawek odbija się i brak jakiegokolwiek nadzoru plastycznego przy ich wytwarzaniu. Na 63 zabawkarskie zakłady spółdzielcze, które przecież dostarczają na rynek niemal połowę wszystkich zabawek - zaledwie trzy posiadają plastyka" (Boergerowa 1960, s. 6). Z czasem sytuacja ulegała poprawie, choć nie była to diametralna zmiana: w 1962 roku na 117 zakładów 9 posiadało komórki wzorcujące. W tym czasie zakłady czerpały nowe wzory z takich źródeł jak:

- własne koncepcje,

- wzory zagraniczne,

- konkursy na nowe wzory zabawek (np. konkurs „Plastuś” organizowany przez Centralny Związek Spółdzielczości Pracy),

- Wzorcownia Centrali Handlowej Artykułów Papierniczych i Sportowych w Łodzi (następca Centralnego Zarządu Handlu Artykułami Użytku Kulturalnego),

- pracownie plastyczne,

- indywidualni plastycy.

$\mathrm{Na}$ początku lat 60. wiele zabawek (także pod względem artystycznym) wymagało poprawy. Aby polepszyć ich jakość, zaproponowano „Zarządowi WZSP 
[w Gdańsku - przyp. M.W.] zaangażowanie znanego plastyka A. [Anny] Smolanowej, której zadaniem byłaby współpraca z tymi spółdzielniami [Spółdzielnią „Powiśle” w Kwidzynie i Spółdzielnią im. Waryńskiego w Kościerzynie] w opracowaniu nowych wzorów, szkoleniu załóg tych spółdzielni oraz stały nadzór nad właściwym wykonawstwem pod względem artystycznym" (Zachariasiewicz 1962, s. 29).

Sukcesem okazały się zabawki produkowane wówczas w Spółdzielni Pracy Wyrobów Zabawkarskich „Mis’” w Łomży. Projektantem coraz to nowych wyrobów powstających w „Misiu” w latach 1961-1974 był plastyk, absolwent Akademii Sztuk Pięknych w Gdańsku, Henryk Osicki. „Jego inwencja artystyczna, znajomość psychiki dziecka, wzbogaciły niepomiernie różnorodność wyrobów" (Borowski 1968, s. 6). W 1967 roku stworzył 21 nowych wzorów, które występowały w różnych wariantach; rok później - 33 (przede wszystkim zwierzęta, wśród nich żyrafy oraz słonie). Według szacunkowych obliczeń $40 \%$ rocznej produkcji stanowiły zabawki wykonane z nowych wzorów, dzięki czemu spółdzielnia wciąż utrzymywała zainteresowanie zagranicznych klientów - aż $80 \%$ wszystkich wyprodukowanych zwierząt, wypchanych wełną drzewną (m.in. lisów i psów) wysyłano (w tym czasie) do Anglii, Holandii, Norwegii, NRF.

$\mathrm{W}$ pierwszej połowie lat 60 . rozpoczęto $\mathrm{w}$ zakładach tworzenie specjalnych działów, tzw. komórek wzorcujących, w których pracę znajdowali projektanci. Aby polepszyć jakość zabawek, CZSP podjęło szereg działań, m.in. „w celu przygotowania odpowiedniego zaplecza technicznego i wzorniczego w 1964 roku zorganizowano komórki projektowo-konstrukcyjne przy 15 zakładach produkcyjnych. W wyniku pracy tych komórek w 1964 roku wprowadzono do produkcji 35 wzorów zabawek mechanicznych i ok. 90 wzorów zabawek politechnicznych. Niezależnie od tego, w roku 1964 rozpoczęto organizację Zakładu Wzornictwa Zabawkarskiego. W tym czasie wprowadzono do produkcji szereg nowych technologii w zakresie obróbki i wykańczania powierzchni zabawek. Do najciekawszych należy: wielobarwne litografowanie blach, malowanie w polu elektrostatycznym, flokowanie i barwienie w bębnach obrotowych" (K.T. 1965, s. 15).

Początkowo w komórkach zatrudniano dwie lub trzy osoby. Na przykład w Spółdzielni Pracy Zabawkarsko-Galanteryjnej w Puszczykowie (funkcjonującej później pod nazwą Zabawkarska Spółdzielnia Pracy w Puszczykowie) wzornictwem zajmowały się na początku lat 60. panie Helena Horostowska-Rynkowska oraz Janina Haberland. Często współpracowano też z projektantką, artystką-plastykiem Ewą Pruską (absolwentką Państwowej Wyższej Szkoły Sztuk Plastycznych w Poznaniu). Z czasem komórka została rozbudowana i liczyła 7-8 osób pełnych nowych po-

${ }^{5}$ Informacja pochodzi z rozmowy z panem Henrykiem Osickim przeprowadzonej w dniu 3 maja 2017 roku. 
mysłów, dlatego w branży mówiono o spółdzielni z Puszczykowa i szytych w niej lalczynych ubrankach, że jest „Diorem strojów dla lalek”.

W tym samym czasie kierownikiem wzorcowni Spółdzielni Pracy Przemysłu Zabawkarskiego „Radość” w Krakowie został Stanisław Dąbrowa-Kostka. „Radość" była wówczas największym producentem drewnianych mebelków dla lalek, np. sypialni o nazwie „Sam”, mebelków „Zosia”, „Koliber” czy kuchenek „Malwa”. Podczas Targów „Wiosna '64” zainteresowanie wzbudzały też produkowane przez spółdzielnię pacynki - zwierzęta (6 różnych), a za kukiełki sceniczne (dostarczane m.in. przedszkolom oraz wysyłane za granicę dla mieszkającej tam Polonii) spółdzielnia otrzymała srebrny medal. Oprócz kukiełek uwagę zwracał ciekawy teatrzyk „Tyci-Tyci”. O wyrobach spółdzielni pisano: „Wysoki poziom artystyczny cechuje ciekawe i bardzo pedagogiczne artykuły Krakowskiej Spółdzielni Pracy «Radość». Są to lalki sceniczne i pacynki zwierzęce - aktorzy teatrzyków kukiełkowych. Lalki sceniczne i dekoracyjne oraz inne rekwizyty projektują artyści-plastycy, a teksty literackie pisane są przez literatów. Odbiorcami lalek scenicznych i pacynek są przedszkola, szkoły i świetlice w Polsce i za granicą. Docierają one nawet do Hongkongu i do Alaski. Spółdzielnia «Radość» otrzymała na «Jesieni '64» srebrny medal i 7 dyplomów" (Z zabawkami już lepiej 1964, s. 17-18).

Pod koniec 1965 roku działało 11 międzyzakładowych, specjalistycznych komórek projektowo-konstrukcyjnych, w których pracowało 60 osób, docelowo planowano zatrudnić 150 pracowników (w 20 komórkach), np. w województwie łódzkim rolę tę spełniała „komórka wzorcująca w spółdzielni «Strykowianka» w Strykowie. Placówka ta wykonuje także modele zabawek dla spółdzielni «Pabianiczanka» w Pabianicach. (...) W stadium organizacji jest międzyspółdzielniana komórka projektowo-wzorcująca przy spółdzielni «Uranium» w Łodzi. Opracowywać ona będzie wzory zabawek z tworzyw sztucznych. Komórka ta będzie również dostarczała wzory spółdzielniom «Spójnia» i «Farmedia» w Łodzi oraz «Strykowianka» w Strykowie” (BK 1966, s. 5)..

Na ciekawy pomysł wpadli łódzcy projektanci, którzy w 1967 roku - nie chcąc tworzyć wzorów „W ciemno” - w pięciu sklepach z zabawkami (m.in. na Piotrkowskiej 42) rozłożyli ankiety z prośbą o wypełnienie. Pozostały jednak puste, więc wysłali list do kilkudziesięciu przedszkoli, w którym informowali, że chcą projektować dobre zabawki, i że aby móc to zrobić, potrzebują wskazówek od osób, które codziennie mają do czynienia z potrzebami najmłodszych. Niestety i tym razem nie otrzymano odpowiedzi - tylko jedno przedszkole odesłało wyczerpującą informację. Dopiero gdy kilka placówek zostało „odgórnie” wyznaczonych przez kuratorium, a projektanci wraz z zabawkami pojechali do małych testerów, udało się poznać opinie dzieci i ich opiekunek.

W 1972 roku utworzono Krajowy Związek Spółdzielni Zabawkarskich, który miał pełnić rolę zjednoczenia wiodącego w branży. Pod koniec roku 1976 w KZSZ 
zrzeszone były 43 spółdzielnie (12 z nich zatrudniało powyżej 500 osób) i zakłady wytwórcze. Oprócz tego cztery zakłady tzw. zaplecza technicznego, handlowego i obliczeniowego. Wśród nich Ośrodek Badawczo-Rozwojowy Przemysłu Zabawkarskiego i Artykułów Politechnicznych w Łodzi. Ponieważ producentom zabawek potrzebna była zarówno pomoc technologiczna, jak i w dziedzinie wzornictwa, rola ta przypadła nowo powstałemu Ośrodkowi. Do jego zadań należało opracowywanie mechanizmów napędowych, sterujących i dźwiękowych stosowanych do produkcji zabawek czy specjalistycznych maszyn oraz narzędzi potrzebnych przemysłowi zabawkarskiemu. $\mathrm{W}$ dziale studiów i analiz miały być prowadzone prace badawcze, dział konstrukcyjny odpowiedzialny był za urządzenia i narzędzia potrzebne w branży, dział technologiczny miał dostosowywać projekty zabawek do warunków zakładów (także przemysłu terenowego i kluczowego, nie tylko spółdzielni), w których miały być produkowane. KZSZ nadał mu charakter zakładu doświadczalnego produkującego urządzenia potrzebne w przemyśle zabawkarskim, zatrudniającego projektantów oraz produkującego zabawki z tworzywa zawierające elementy dźwięku oraz różne typy napędów.

W celu doskonalenia działalności zakładowych wzorcowni i prototypowni od 1979 roku podejmowano takie działania, jak organizowane przez Ośrodek Badawczo-Rozwojowy co dwa lata ogólnokrajowe narady projektantów zabawek, na których poruszano kwestie funkcji zabawek, wzornictwa, metodyki projektowania czy potrzeb odbiorcy. Podczas pierwszego spotkania odbywającego się w dniach 17-18 grudnia 1979 roku wygłoszono m.in. referaty dotyczące wzornictwa zabawek miękkich (a aktualnie występujących warunków), zabawek w rehabilitacji dzieci czy problemów projektantów przy projektowaniu zabawek mechanicznych $\mathrm{z}$ napędem elektrycznym.

\section{NAJCIEKAWSZE WZORNICTWO}

Już od lat 50. polskie zabawki tzw. miękkie cieszyły się dużym powodzeniem. Ze względu na sposób produkcji, były to wyroby „hand made”. W całym omawianym okresie branża tkaninowa wyróżniała się najciekawszym wzornictwem. W spółdzielniach produkujących zabawki z tkanin powstało najwięcej pracowni projektowych i najczęściej wprowadzano nowe wzory. W Spółdzielni Pracy „Plecionka” we Wrocławiu oryginalne zabawki projektowała Teresa Forowicz.

W 1968 roku wzór jednej z lalek (autorstwa Teresy Forowicz, Wiesława Bartnickiego i Aleksandra Czerwińskiego) zgłoszono do Urzędu Patentowego PRL. Na początku lat 70. w „Plecionce” produkowano lalki „Pyza”, „Jaga”, „Klaudia”, „Pamela” oraz Klauny i Mikołaje. Lalki eksportowano wówczas do 25 państw, za 
granicę wysyłano ponad $80 \%$ produkcji. Ogromnym powodzeniem cieszyła się lalka „Pepi” - w 1971 roku zagraniczni klienci złożyli rekordowe zamówienie na 60 tysięcy sztuk tych lal. Najwięcej eksportowano do krajów skandynawskich, Beneluksu, Anglii, Włoch, NRF. Zagranicznym odbiorcom podobało się pomysłowe wzornictwo (w 1970 roku opracowano 52 wzory lalek - m.in. „Agę”, „Bila”, „Petera”, „Donalda”, „Gogo” i „Mario” oraz 48 modeli teczek i tornistrów szkolnych). Na stanowisku Teresę Forowicz zastąpiła Ewa Lorek a potem Halina Haligowska.

W 1989 roku pisano „Najlepsze osiągnięcia w ostatnich latach miały: Halina Kalinowska [najprawdopodobniej chodziło właśnie o Halinę Haligowską], Barbara Sulikowska, Elżbieta Wysogląd [Spółdzielnia Pracy Przemysłu Zabawkarskiego „Świętokrzyska”], Halina Wasiak [pracowała w Spółdzielni Pracy „Powiśle” w Kwidzynie - przyp. M.W.]. Projektantki te w ciągu kilku lat swojej pracy potrafiły stworzyć własny styl projektowanych zabawek oraz własny styl pracy, odbiegający od konwencjonalnych metod stosowanych przy projektowaniu przemysłowym. $\mathrm{Na}$ ich pracach można najlepiej obserwować ewolucję wzorów, rozwój artystyczny ich indywidualnej twórczości i jakościowy rozwój wyrobów poszczególnych spółdzielni. (...) Efektem ich pracy były liczne nagrody w konkursach «Dobre Ładne - Poszukiwane», organizowanych przez MHWiU [Ministerstwo Handlu Wewnętrznego i Usług], na najciekawszą zabawkę targów poznańskich i giełdy łódzkiej, indywidualne nagrody na wystawie projektów zabawek Związku Artystów «Polska Sztuka Użytkowa» i innych" (Materiały sprawozdawcze na IX Zjazd Delegatów, 1989, s. 28).

Zabawki miękkie wykonywali także uczniowie Państwowego Liceum Technik Plastycznych w Nałęczowie (dziś to Liceum Plastyczne im. Józefa Chełmońskiego). Projektowane w szkole zabawki zdobywały nagrody, m.in. na Targach w Poznaniu. „Źródło swych sukcesów twórcy z Nałęczowa widzieli w znajomości psychologii dziecka, w zachowaniu w zabawkach cech twórczości rodzimej, «ludowej» oraz w stosowaniu niekonwencjonalnych materiałów, jak len, konopie, obiciówka itp." (Bujak 1988, s. 158). Mimo tego iż w liceum powstawały piękne zabawki, szkoła nie współpracowała z producentami - a i oni nie nawiązywali bliższych kontaktów z placówką. Do 1972 roku tylko kilka modeli zostało wdrożonych do produkcji, dziesiątki zalegało w szkolnych magazynach. Choć w 1971 roku została przygotowana umowa między szkołą a CZSP i „Coopeximem” (przedsiębiorstwem pośredniczącym w eksporcie m.in. zabawek), jednak co najmniej przez rok czekała na podpisanie. Absolwentki tej szkoły znajdowały jednak pracę w niektórych zakładach - przede wszystkim w Zabawkarskiej Spółdzielni Pracy „Bajka” w Lublinie oraz w Spółdzielni Pracy „Miś” w Siedlcach.

Siedlecki „Miś” był jedną z największych spółdzielni zabawkarskich w Polsce. We własnej wzorcowni (w której pracowało łącznie 10 osób, w tym dwóch arty- 
stów plastyków) tylko w 1973 roku powstało ok. 90 wzorów zabawek, wszystkie wdrażano do produkcji. Dobrze zaprojektowane i wykonane cieszyły się powodzeniem - wpływ na to miało też częste wprowadzanie nowych modeli - jeden wzór zabawki miękkiej wytwarzano maksymalnie dwa lata a zabawki z tworzyw sztucznych - najdłużej przez pięć lat. W 1974 roku na rynek wprowadzono 32 nowe wzory zabawek, m.in. piszczki harmonijkowe oraz nowe wzory lalek z polietylenu. Jednak jedną z najsławniejszych zabawek, które powstały w „Misiu”, była maskotka odbywających się w lutym 1982 roku w Sarajewie Zimowych Igrzysk Olimpijskich. Jedną z współautorek wzoru Wilczka była projektantka Maria Sobota. Poza tym wśród projektantek były: Henryka Bąbel, Maria Rykała, Barbara Czapska, Renata Wiśniewska czy Jolanta Puszkowska.

\section{PROBLEMY PRZEMYSŁU}

Branża zabawkarska w czasach PRL-u nie miała swojego „opiekuna” wśród władz państwowych. Stwarzało to szereg problemów - przede wszystkim surowcowych. Począwszy od lat 50. zaopatrzenie (niezależnie od materiału; czy był to celuloid, skóra czy blacha) było nie tylko nieregularne, ale dostawy surowców nie pokrywały potrzeb. Między innymi z tego powodu ładne i estetyczne zabawki - by przysporzyć krajowi dewizy - wysyłano za granicę, do polskich sklepów trafiały te gorszej jakości lub z mniej przyjemnych materiałów.

Podczas Poznańskich Targów „Wiosna '65” odnotowywano „szczególny ruch na stoisku Siedleckich Zakładów Przemysłu Zabawkarskiego [późniejsze Podlaskie Zakłady Wytwórcze - przyp. M.W.] w pawilonie nr 20. Największym zainteresowaniem, tak zwiedzających, jak i handlowców, cieszą się zabawki wykonane z naturalnych futer. Do produkcji tych zabawek wykorzystuje się przede wszystkim skóry baranów australijskich, kozic włoskich i królików. Rzecz jasna, że import tych surowców jest sprawą niełatwą i dlatego produkcja pięknych piesków, misi, małpek na rynek krajowy jest stosunkowo niewielka. Najlepiej świadczą o tym cyfry. Roczna wartość produkcji zakładów wynosi około $35 \mathrm{mln}$ złotych z czego $30 \mathrm{mln}$ złotych towarów wysyła się na rynki zagraniczne" (Informacja prasowa Targi Krajowe „Wiosna - 65”, 1965, s. 5).

Brak odpowiednich surowców rzutował też na rytmiczność produkcji. W lutym 1978 roku w produkcji zabawek miękkich brak było pluszu, gąbki lateksowej, wiskozy, trykotu i wielu innych dodatków, bez których nie można było zakończyć zleceń, opracowywano więc wzory zabawek, które można było wykonać z dostępnych surowców. Najgorszym momentem był jednak kryzys lat 1981-1982. W tym czasie w spółdzielni „1 Maj” z Włocławka (gdzie w latach 80. projektantką była 
Aldona Ołdyńska) w związku z brakiem surowców niezbędnych do produkcji lalek, w zakładzie rozszerzono asortyment (o wyroby, które wymagały mniejszych starań): szyto materace (z odpadów z gąbki poliuretanowej) oraz wielobarwne poduszki ( $w$ żywych kolorach, np. w biało-czerwone czy w biało-zielone kratki wypychane ścinkami, np. resztkami włókien pochodzących z toruńskiej „Elany”). Gdy zdobyto tkaninę frotte, szyto ręczniki, gdy płótno - worki na obuwie szkolne.

Kolejną bolączką był czas, jaki upływał od zaprojektowania zabawki do jej produkcji seryjnej. Droga od powstania projektu na papierze sporządzonego przez plastyka poprzez przygotowanie dokumentacji zabawki, wykonanie modelu i dokumentacji oprzyrządowania i form potrzebnych do uruchomienia produkcji seryjnej była długa, w przypadku zabawek mechanicznych były to dwa lata. Zdarzało się, że zabawka zdążyła się przez ten czas „zdezaktualizować”. Poza tym, oprócz panującej także w branży zabawkarskiej mody, ważne było również dostosowanie projektu do aktualnie obowiązujących czasów. Wyrazem tego miało być wprowadzenie do sprzedaży (równocześnie z momentem ukazania się na drogach polskiego fiata) miniaturowego modelu auta, sterowanego zdalnie za pomocą gwizdka. Od początku lat 60. spółdzielnia „Palart” z Wrocławia wyszła naprzeciw zainteresowaniom ludzi sferą nieba, rozwojem techniki rakietowej i zaczęła produkować zabawki związane z tymi tematami.

Przemysłowi doskwierał także brak wykwalifikowanych pracowników. Żadna uczelnia nie kształciła projektantów zabawek, nie było też w Polsce zawodu „zabawkarz" (choć w niektórych państwach taki kierunek można było studiować na politechnikach). Zagadnienie to omawiane było szeroko w latach 1971-1972 zarówno na szczeblu CZSP jak i w branżowej prasie. Na jej łamach ${ }^{6}$ pisano o projekcie stworzenia szkół, w których byłby profil zabawkarski. Technikum o specjalizacji zabawkarskiej miałyby być utworzone w ramach szkolnictwa CZSP przy Zespole Szkół Zawodowych Centralnego Związku w Łodzi, a zasadnicza szkoła zawodowa również o tej samej specjalizacji - przy Zespole Szkół Zawodowych w Bydgoszczy. Z kolei w 1973 roku wspominano o nawiązaniu współpracy z Technikum Plastycznym w Nałęczowie oraz z podobnego typu ZSZ w Cieplicach. Spółdzielnie radziły sobie na różne sposoby - np. siedlecki „Miśs” prowadził przyzakładową klasę o specjalności zabawkarskiej. Zwiększono też szkolenie systemem przywarsztatowym - ponieważ wielu wyspecjalizowanych pracowników zaczęło odchodzić na emeryturę, potrzebni stali się młodsi, którzy mogliby ich zastąpić. W ten sposób do 1976 roku wyszkolono 2400 osób, jednak jak na potrzeby stale rozwijającego się przemysłu nie była to ilość wystarczająca.

${ }^{6}$ Patrz: R. Musiał, Świat współczesny w miniaturze, Spółdzielczość Pracy 1973 nr 3, s. 2; (AS), Zaplecze przemysłu zabawkarskiego, Spółdzielczość Pracy 1973 nr 17, s. 3; R. Musiał, Szkolenie kadry dla przemystu przyszłości, Spółdzielczość Pracy 1973 nr 38, s. 2. 


\section{ZADANIA PROJEKTANTA}

Aby zabawka była udana, potrzebna jest też podstawowa wiedza na temat dzieci - ich rozwoju zarówno fizycznego, jak i psychicznego. Dobra zabawka powinna rozwijać sprawność ruchową oraz umysłową, „bogacić jego [dziecka] życie emocjonalne, przygotowując do czynnego udziału w życiu społecznym, rozwijać wyobraźnię (...), wyrabiać w dziecku samodzielność i wytrwałość przy realizowaniu podjętych zadań, wzmacniać jego motywację, uczyć współdziałania w zespole i zachęcać do przezwyciężania trudności (...)" (Dunin-Wąsowicz 1975, s. 24). Dlatego poznanie zainteresowań i potrzeb dziecka w określonym wieku powinno być podstawowym zadaniem projektanta. Aby powstała dobra zabawka, projektant powinien współpracować ze specjalistami z różnych dziedzin - psychologiem, pediatrą lub placówką naukową badającą potrzeby dziecka oraz z technologiem produkcji.

Kolejnym krokiem powinno być zaznajomienie się $\mathrm{z}$ aktualnie produkowanymi i dostępnymi zabawkami - aby nie powielać wzorów. I tak np. w połowie lat 70. prawie nie było lalek przedstawiających chłopców oraz niemowlęta (może dlatego takim hitem okazał się produkowany dekadę później przez Spółdzielnię w Puszczykowie bobas). Na łamach prasy pytano „Skąd zresztą brać nowe, ciekawe wzory? Zaplecze projektowe spółdzielni zrzeszonych w krajowym związku jest bardzo skromne, a z usług plastyków-projektantów korzysta się bardzo rzadko. Przyczyn jest kilka. Producenci uważają zwykle, że nie ma potrzeby zamawiać projektów u ludzi z zewnątrz, bo za te same pieniądze można projektować we własnym zakresie. Plastycy wolą zaś bardziej intratne zajęcia, a jeśli już ktoś zdecyduje się poświęcić zabawkom, to szybko go do tego zniechęcają trudności ze znalezieniem producentów i odpowiednich materiałów. Jednym słowem błędne koło" (Zatorska 1983, s. 7).

Z tego też powodu w Spółdzielni Pracy „Galanteria Drzewna” w Mrągowie na przykład przez co najmniej dwa lata (1973-1975) był nie obsadzony etat projektanta zabawek. Pomocą służył Ośrodek Badawczo-Rozwojowy Przemysłu Zabawkarskiego w Łodzi, choć ambitne zamierzenia nie zawsze udawało się zrealizować - w 1977 roku KZSZ planował wprowadzić 505 nowych wzorów, z przyczyn niezależnych (braku odpowiednich surowców) wykonanych zostało zaledwie 329 sztuk. Zamówienia z zagranicy realizowane były najczęściej wg wzoru przysłanego przez zamawiającego. W filii spółdzielni z Łomży wzory przysłane przez kontrahenta opracowywały brygadzistki wraz z pracownicami. Wymyślone na miejscu projekty wysyłane były do „Coopeximu”, gdzie rzeczoznawcy wyrażali zgodę (bądź nie) na rozpoczęcie produkcji serii. Ponieważ komórka techniczna była niewielka, opracowanie wzoru pochłaniało sporo czasu.

Pracujący w spółdzielniach plastycy byli często absolwentami Akademii Sztuk Pięknych (zazwyczaj wydziału projektowania odzieży) lub modelarstwa. Co praw- 
da już w połowie lat 60. CZSP planował „dostosowanie programu nauczania co najmniej 2 techników spółdzielczych [w Gdańsku i Puławach - przyp. M.W.] do kształcenia techników-technologów produkcji zabawkarskiej oraz opracowanie i zaktualizowanie programu szkolenia przywarsztatowego i w oderwaniu od pracy” (K.T. s. 16) oraz „rozszerzenie kształcenia projektantów zabawek w trzech wytypowanych liceach technik plastycznych przy równoczesnym przekształceniu liceum w Nałęczowie w specjalistyczne liceum zabawkarskie, ustalenie stypendiów dla uczniów techników i liceów plastycznych, dostosowanie programów nauczania w ok. 5 wytypowanych szkołach zawodowych - do szkolenia wykwalifikowanych robotników przemysłu zabawkarskiego" (Ibidem), ponieważ do realizacji tych planów konieczna była zgoda Ministerstwa Oświaty na wpisanie do nomenklatury zawodów zawodu „zabawkarza”, nie zrealizowano zamierzeń.

Mimo wielu prób, rozmów i tworzeniu nowych ośrodków, sytuacja w branży zabawkarskiej nie ulegała poprawie - coraz bardziej polskie zabawki, przez lata nieunowocześniane, pozostawały w tyle za produktami z zachodu. Wieloletni dyrektor kieleckiego Muzeum Zabawek i Zabawy, a przy tym autor wielu publikacji na omawiany temat, Ryszard Zięzio, o sytuacji panującej wśród producentów pod koniec lat 80. pisze w następujący sposób: „W bardzo nikłym stopniu korzysta się z usług zawodowych projektantów i własnych pracowni projektowych, z wyjątkiem niektórych spółdzielni branży tkaninowej, gdzie stosunkowo najłatwiej wprowadzić zmiany, a często są one konieczne w związku z brakami surowców do wytwarzania dłuższych serii, sprawdzonych już zabawek. W tej branży powstały też najliczniej zakładowe pracownie projektowe. Podyktowane to jest przede wszystkim koniecznością wprowadzania zmian do projektów bezpośrednio w czasie procesu produkcyjnego. Rolę wiodącą we wprowadzaniu nowych wzorów przyznać należy Spółdzielniom: «Plecionka» we Wrocławiu, «Światowid» w Warszawie, «Miś» w Siedlcach a ostatnio «Świętokrzyska» w Kielcach i Młodzieżowa Spółdzielnia Zabawkarska w Skierniewicach" (Zięzio 1988, s. 18-19).

Wynikało to $\mathrm{z}$ tego, iż wymienione spółdzielnie podjęły współpracę z absolwentami Liceum Sztuk Plastycznych z Nałęczowa, co zaowocowało (pomijając ciekawe wzorniczo zabawki) lepszymi wynikami finansowymi, dużym udziałem w eksporcie oraz przyznanymi nagrodami (w konkursie „Na najciekawszą zabawke” organizowanym przez Muzeum Zabawkarstwa w Kielcach oraz „Dobre - Ładne - Poszukiwane"). 


\section{PODSUMOWANIE}

Niektóre rzeczy pozostawały bez zmian - nadal nie zawsze udawało się skonstruowanie przedmiotu zgodnego z wizją projektanta. Piszą o tym autorzy w wydanej w 1988 roku publikacji Dla kogo zabawka?. Szczególnie dosadnie podsumowuje występujące zjawisko Barbara Perzyna-Przymusińska w artykule pod wiele mówiącym tytułem Dlaczego projektant, producent $i$ dystrybutor nie moga zrealizować swoich ambicji?. Z tekstu można dowiedzieć się, że w Polsce nie produkuje się „typowych, przeznaczonych wyłącznie dla zabawkarstwa, wydajnych maszyn specjalistycznych do obróbki drewna i produkcji z tworzyw sztucznych. Większość zabawek jest wykonywana na maszynach uniwersalnych, adaptowanych z innych gałęzi przemysłu i nie nadających się do stosowania różnorodnych metod obróbki. Nie produkuje się specjalnie dla zabawkarstwa takich podzespołów, jak: mechanizmy ruchu, mechanizmy dźwiękowe do zabawek muzycznych, pozytywki, różnego typu zawory. Nadal nie rozwinięto wielu niezbędnych technologii. (...) Zabawkarstwo nie znajduje oparcia w przemyśle lekkim, chemicznym, elektronicznym i innych. Nie dysponuje wysokiej jakości tkaninami o trwałych kolorach, lakierami nietoksycznymi, odpowiednimi tworzywami sztucznymi w zadawalającej ilości, sitodrukami, kalkomaniami, małymi guziczkami, haftkami, taśmami. Listę można by jeszcze wydłużyć o wiele innych materiałów" (Perzyna-Przymusińska 1989, s. 21-22). A Jerzy Górski w tej samej publikacji stwierdza: „zabawka to zwierciadło możliwości produkcyjnych naszego kraju” (Górski 1989, s. 23).

Jak w zwierciadle sytuacja ekonomiczno-polityczna państwa odbiła się na przedsiębiorstwach produkujących zabawki - po 1989 roku większość z nich przestała istnieć. Paradoksalnie więc, mimo zniesienia dotychczasowych ograniczeń (np. w dziedzinie zaopatrzenia w surowce) i nowym możliwościom, projektanci zabawek musieli zmierzyć się z kolejnymi - choć innego rodzaju - trudnymi sytuacjami.

\section{LITERATURA}

AS, 1966, Medaliści maja głos.... „Spółdzielczość Pracy”, nr 13, s. 1.

BK, 1966, Coraz więcej komórek wzorcujących. „Spółdzielczość Pracy”, nr 12, s. 5.

Boergerowa K., 1960, O zabawkach uwagi nie zabawne. „Nowiny Rzeszowskie”, nr 30, s. 6.

Borowski P., 1968, W łomżyńskim „Misiu”. „Spółdzielczość Pracy”, nr 50, s. 6. Bujak J., 1988, Zabawki w Europie. Zarys dziejów - rozwój zainteresowań. Kraków, Wydawnictwo Uniwersytetu Jagiellońskiego. 
Dunin-Wąsowicz M., 1975, O zabawce w ręku dziecka. Warszawa, Wydawnictwo „Watra”.

Górecka M., 2009, Wzornictwo zabawek polskich w ostatnich latach PRL. Wizje, produkcja, codzienność. „Zabawy i Zabawki”, nr 1-4, 161-172.

Górski J., 1989, Nowoczesna zabawka dla małego dziecka - jej wartość rozwojowo-dydaktyczna., w: J. Bukowski (red.), Dla kogo zabawka? Warszawa, Instytut Wzornictwa Przemysłowego, s. 23.

K.T., 1965, Zamierzenia rozwojowe przemysłu zabawkarskiego, „Przegląd Drobnej Wytwórczości”, nr 20, s. 15.

Komitet Drobnej Wytwórczości, Informacja prasowa Targi Krajowe „Wiosna - 65”, Poznań 1965, s. 5.

Materiały sprawozdawcze na IX Zjazd Delegatów, 1989, Krajowy Związek Spółdzielni Zabawkarskich w Kielcach, Kielce, s. 28.

Perzyna-Przymusińska B., 1989, Dlaczego projektant, producent i dystrybutor nie moga zrealizować swoich ambicji? W: J. Bukowski (red.), Dla kogo zabawka? Warszawa, Instytut Wzornictwa Przemysłowego, s. 21-22.

Piętowski T., Witaczek W., 1957, Zabawki z tkanin. Warszawa, Wydawnictwo Przemysłu Lekkiego i Spożywczego.

Rozwój produkcji zabawkarskiej, 1987. „Studia i Materiały”. Zeszyt 1, Kielce, s. 9. Strzelec J., 1989, Spółdzielnia Zabawkarska Gromada. Trudne początki $i$ wytrwałe tworzenie. „Studia i materiały”, Kielce, s. 51.

Zachariasiewicz W., 1962, Produkcja eksportowa spółdzielni pracy województwa gdańskiego. „Informacje Coopeximu 6”, s. 29.

Zatorska U., 1983, Nie podkładać dzieciom świni. „Życie Gospodarcze”, nr 22, s. 7.

Zięzio R., 1988, Charakterystyka zmian asortymentowych $w$ produkcji zabawek a zapotrzebowanie rynku. Sprawozdanie z wstępnych badań sondażowych Muzeum Zabawkarstwa w Kielcach w latach 1985-1987. „Studia i Materiały”, Zeszyt 1, Kielce, s. 18-19.

Z zabawkami już lepiej, 1964. „Przegląd Drobnej Wytwórczości”, nr 20, s. 17-18.

\section{CREATIVITY OF TOY DESIGNERS EMPLOYED IN LABOUR CO-OPERATIVES IN THE PEOPLES REPUBLIC OF POLAND AND LIMITING FACTORS THEREOF}

\footnotetext{
Abstract: In 1980 Janos Kornai published a work entitled „The shortage economy”. Therefore he defined the centrally controlled communist economy. Also in the Polish People's Republic, a country where, after World War II, the Polish United Workers' Party took power, many articles were missing. Although people living in the times of the People's Republic of Poland
} 
remembered mainly the lack of basic food or industrial products, also the quantity (and quality) of toys left much to be desired. Not only fabrics, raw materials and other materials needed for the production of toys were missing, but also specialized machinery and other equipment. There were also not enough qualified employees. For this reason, not every toy company employed its own designers during the Polish People's Republic period. Despite this, many interesting designs were created in labor cooperatives (because that's where a large proportion of dolls or toy cars were made). In the article I described both: the activities of the factory mills and the prototyping workshops, and I name the designers working in the toy industry.

Key words: toys, the Peoples Republic of Poland, creativity, designers, history, cooperatives 